トリオキサンとエチレンオキシドとの共重合の初期反応過程の 解析2-1,3,5,7,10-ペンタオキサシクロドデカンの生成

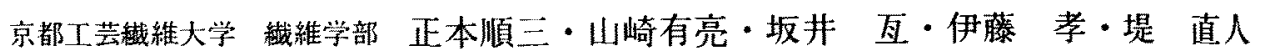
京都工芸繊維大学 工芸学部 大西宣昭 旭化成工業侏テナック開発・技術部 永原 肇

\title{
Analysis of the Reaction in the Early Stage of the Copolymerization of Trioxane and Ethylene Oxide. 2-Formation of 1,3,5,7,10-Pentaoxacyclododecane
}

\author{
Junzo Masamoto ${ }^{* 1}$, Naoaki Yamasaki ${ }^{* 1}$, Wataru Sakai ${ }^{* 1}$, Takashi Itoh ${ }^{* 1}$, \\ Naoto Tsutsumi ${ }^{* 1}$, Nobuaki Ohnishi*2, and Hajime Nagahara*3,
}

${ }^{* 1}$ Department of Polymer Science and Engineering, Kyoto Institute of Technology, Matsugasaki, Sakyo-ku, Kyoto 606-0000 Japan

${ }^{* 2}$ Department of Chemistry and Material Technology, Kyoto Institute of Technology, Matsugasaki, Sakyo-ku, Kyoto 606-0000 Japan

${ }^{* 3}$ Tenac Development and Technology Department, Asahi Chemical Industry Co., Ltd. Kojimashionasu, Kurashiki, 711-0000 Japan

\begin{abstract}
In a previous report, we noted a new direct reaction between 1 mole of trioxane and 1 mole of ethylene oxide and the formation of a novel cyclic formal of 1,3,5,7-tetraoxacyclononane. We have now determined a new reaction and novel cyclic compound from the reaction of trioxane and ethylene oxide. The novel cyclic compound was separated and collected using a micro-distillation apparatus and gas chromatographic method. Its chemical structure was confirmed using ${ }^{1} \mathrm{H} \cdot \mathrm{NMR},{ }^{13} \mathrm{C}-\mathrm{NMR}$, mass spectrum and elemental analysis. The new isolated novel cyclic compound was 1,3,5,7,10-pentaoxacyclododecane, which might be formed by the direct reaction of 1 mole of trioxane and 2 moles of ethylene oxide. In the commercial base acetal copolymer, which was produced by the copolymerization of trioxane and ethylene oxide, it is known that there is a consecutive two units sequence of ethylene oxide, and this consecutive 2 ethylene oxide unit sequence might be postulated to come from the ring opening-polymerization of the novel cyclic formal of
\end{abstract} 1,3,5,7,10-pentaoxacyclododecane.

(Received 12 January, 1998 ; Accepted 23 February, 1998)

\section{1. 緒言}

オキシメチレンを繰り返し単位とするポリオキシメチ レンはポリアセタ一ル樹脂と一般的に呼ばれ，金属に置 き代わるエンジニアリングプラスチック(略してエンプラ) として広く用いられている。ポリアセタール樹脂は一般
的にはホルムアルデヒドの単独重合(アセタールホモポリ マー)、またはトリオキサンとエチレンオキシドとの共重 合(アセタールコポリマー)の両者が生産されている.

ポリアセタール樹脂の製法についてのホルムアルデ ドの重合に関寸る研究の報告例は概して多〈ない: 方、トリオキサンの共重合に関寸る研究例は数多く報告 
されているが，大部分はトリオキサンとジオキンランと の共重合に関する学術的な研究である。しかしながら， 現実の化学工業で生産されているトリオキサンとエチレ ンオキシドとの共重の研究は工業的な見地からも学術的 な見地からも重要であるにもかかわらず，これまでの所 研究報告は概して少ない ${ }^{7 \sim 12) . ~}$

我々はトリオキサンとエチレンオキシドの共重合の初 期反庶過程について研究を行っている際に従来の報告で は起こり得ないとされていた オキシドとの直接反応という新しい反応が生じることを 見出した ${ }^{133}$ ．また，その反応により，従来見出されてい なかった不安定な中間体が生じそその中間体が新規な環 状化合物であることを見出した，前報では，その反応の 主生成物が 1 モルのトリオキサンと1モルのエチレンオ キシドとより構成される1,3,5,7-テトラオキサシクロ， ナンであることを明らかにした ${ }^{13)}$.また, 前報では, 1,3,5,7テトラオキサシクロノナンよりトリオキセパンが生成し， ついでシオキソランが生成することを明らかにした。こ れらの化合物はトリオキサンと共重合することにより， 共重合体にオキシエチレンユニットを与える。さらに我々 はトリオキサンとエチレンオキシドとの反応について检 討を進めたところ，2 個の連続したエチレンオキシドユ ニットとトリオキサンとから成り立つ新たな新規環状化 合物の生成を見出した。この新規環状化合物はトリオキ サンと開環共重合することにより，2 個の連続したオキ シエチレンユニットを与えると思わ机る。すなわち、卜 リオキサンとエチレンオキシドとの共重合で生成する2 個の連続したオキシエチレンユニットはここで見出され な新規環状化合物より由米すると思われる。ここでは， その新規環状化合物の構造を同定したので報告する。

\section{2. 実験}

\section{1 試料}

トリオキサンは旭化成工業株式会社より提供された精 製トリオキサンを使用した。

エチレンオキシドは市販のエチレンオキシド $(5 \mathrm{~kg}$ ボン ベ入り)をそのまま精製することなく使用した。

共重合の開始剤として $\mathrm{BF}_{3} \cdot \mathrm{OBu}_{2}$ を用いた $\mathrm{BF}_{3} \cdot \mathrm{OBu}_{2}$ は減压下で蒸留を行い，ガラスアンプルに封入し冷蔵庫 に保管して使用前に開封して用いた。

\section{2 反店}

反応は工業的に実施されているバルク重合とし，エチ レンオキシドの量も工業的に実施されている条件とほほ 等しくした97.100mLのガラス製三つロフラスコにトリオ

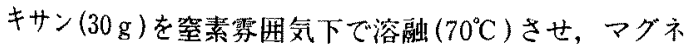
チックスタラーで観拌させながら所定量のエチレンオキ シド(トリオキサンに对して4.5mol\%)を溶解させたのち， シクロヘキサンで希釈した $\mathrm{BF}_{3} \cdot \mathrm{OBu}_{2}$ (トリオキサンに対 して7 $\times 10^{-5} \mathrm{~mol} / \mathrm{mol}$ )を反応器にマイクロシリンジにて注 入し、 $70^{\circ} \mathrm{C}$ 常圧で反応させた、触媒注入後, 反応器から 注射器で反応混合物を約 30 秒間隔で抜き出し, 微量の $\mathrm{KOH}$ を溶解させたn-PrOH中で反応を停止させた。

\section{3 反応物より新規環状化合物の分離}

反応混合物は大科工業侏)製taikaミク口蒸留器(理諭段： 15段)を用いて常圧蒸留で分離した。蒸留物として1,3,5,7テトラオキサシクロノナンを取り出した後, 蒸留残査を ミクロ蒸留装㯰に移し，蒸留鉒をオイルバスに浸漬し， オイルバス温度 $182^{\circ} \mathrm{C}$, 減圧度4torrの条件下で減圧蒸留を 行い，留出物を得た。この留出物についてTCD検出器を 備えたガスクロ島津GC-4Aを使用し，ガスクロ分取を行 つた，分取条件は次の通りである。ガラス製の充填力ラ ム(カラム径 $4.0 \mathrm{~mm}$, 力ラム長 $2 \mathrm{~m}$, 存填剂として液相Silicone OV-17を $10 \%$ 含有した処理Chromosorb W) を使用し、気

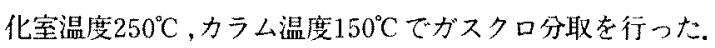
1 度目の分取物を再度がスクロ分取することにより分離 度を完全なものとした。

\section{4 分析}

反応解析はガスクロマトクラフィーを用いて行った。 J\&W SCIENCE社製メチルシリコンキャピラリーカラム DBー1 (溶融シリカにメチルシランを被覆)を使用し、FID 検出器を備えた昇温型ガスクロ島津GC-14Aを使用した。

構造物の同定には400MHzNMR(JEOL JNM-AL400 FT NMR System Spectrometer) t使用 L, ${ }^{1} \mathrm{H}-\mathrm{NMR}$ 打 よび13 $\mathrm{C}-\mathrm{NMR}$ 测定を行った。溶媒として $\mathrm{CDCl}_{3}$ を使用し た。

質量分析は日本電子JMS-700MStationを使用し, 分子 量, 組成式を求めた。測定方法はEI測定で70eVで行った。

\section{3. 結果および考察}

\section{1 新規環状化合物の構造決定}

新規な反応中間体(新規環状化合物)はガスクロ分取に より採取した。

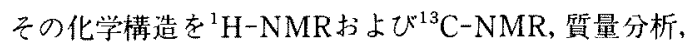
微量元素分析により確認した。

图 1 は新規化合物の ${ }^{1} \mathrm{H}-\mathrm{NMR}$ 示寸.そのチャート図 より,この新規環状化合物は1 $3,5,7,10$-ペンタオキサシ クロドデカンと推定された，1モルのトリオキサンと2 モルのエチレンオキシドの直接反応が生じたことを示し ている。なお， $\mathrm{Ha}$ (ホルマール結合のプロトン,ケミカル シフト: $5.00 \mathrm{ppm}), \mathrm{Hb}$ (ホルマール結合のプロトン, ミカルシフト: $4.90 \mathrm{ppm}), \mathrm{Hc}$ (エーテル結合のプロトン, ケミカルシフトは3.83 -3.85ppm，5 本線)およびHd(エ 

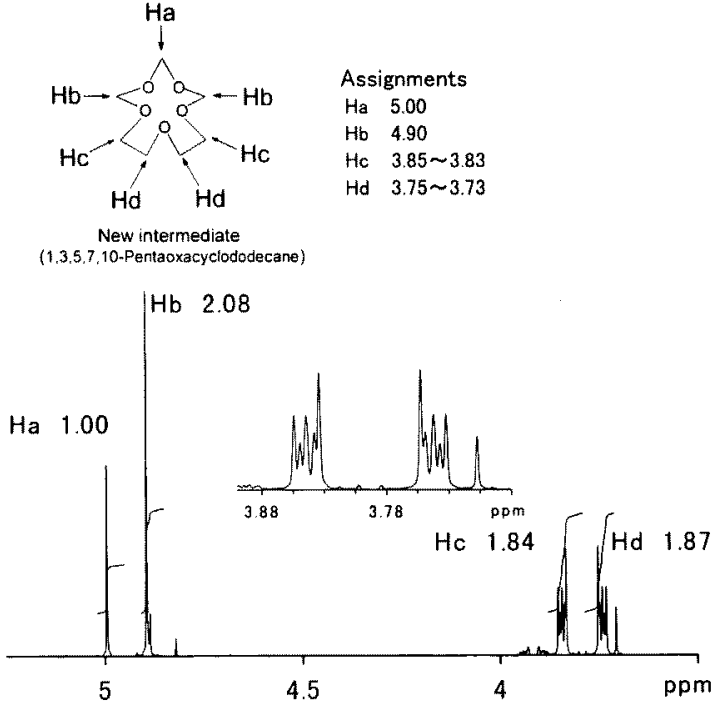

Fig. $1{ }^{1} \mathrm{H}$-NMR pattern of the new intermediate

一テル結合のプロトン,ケミカルシフトは3.73 3.75ppm, 5 本線)の比は1 ( $\mathrm{Ha}): 2(\mathrm{Hb}): 2$ (Hc) : 2(Hd)であり, $1,3,5,710$-ヘンタオキサシクロドデカンの化学構造式と 一致することが確かめられた。なお，HcおよびHdは图 1 の拡大图に示すようにスピンースピン結合により $3.79 \mathrm{ppm}$ を中心として左 $(3.83 \sim 3.85 \mathrm{ppm})$ 右 $(3.73 \sim 3.75 \mathrm{ppm}) に$ それぞれ5本づつの对称なシグナルに分裂している。

図 2 は新規化合物の ${ }^{13} \mathrm{C}-\mathrm{NMR}$ 示才.この図は 4 つの 相翼なる炭素原子の存在を示している。Ca（ホルマール結 合の炭素,ヶミカルシフト: $95.1 \mathrm{ppm}), \mathrm{Cb}$ (ホルマール 結合の炭素, ケミカルシフト：95.9ppm), C C (エーテル
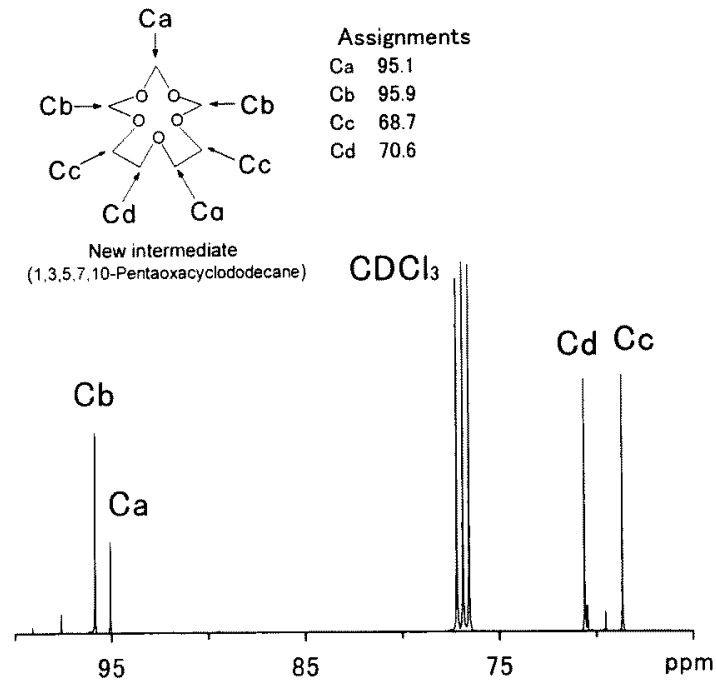

Fig. $2{ }^{13} \mathrm{C}-\mathrm{NMR}$ pattern of the new intermediate

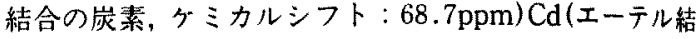

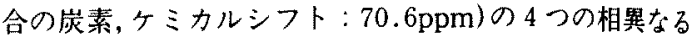
炭素原子の存在は1 $1,3,5,7,10$-ペンタオキサシクロドデ力 ンの化学構造式と一致することが確かめられた。

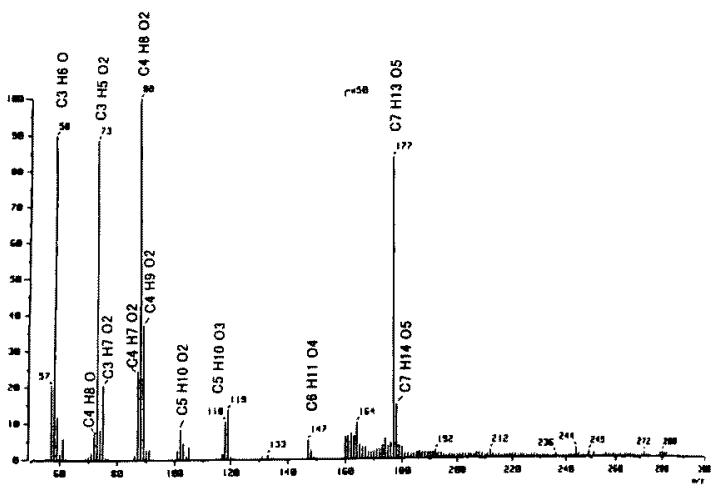

Fig. 3 EI mass spectrum of the new intermediate

図 3 は新規罯状化合物のEIマススペクトルを示す。分 子量177が強〈示され，またその組成式は $\mathrm{C}_{7} \mathrm{H}_{13} \mathrm{O}_{5}$ となり， これは1，3，5，7，10-ペンタオキサシクロドデカン(組成式 $\left.\mathrm{C}_{7} \mathrm{H}_{14} \mathrm{O}_{5}\right)$ 上りプロトンが一つ脱離したものと一致する. な㧍，弱いながらも，分子量178のシグナルも示され，こ れは1,3,5,7,10ーペンタオキサシクロドデカン(組成式 $\mathrm{C}_{7} \mathrm{H}_{14} \mathrm{O}_{5}$ ，分子量178) と完全に一致している.

また,微量元熬分析值は炭素含量の実測値が $47.25 \mathrm{wt} \%$ であり，計算值の $47.19 \mathrm{wt} \%$ と良い一致を示した。また。 水素含量の実測値も8.06wt\%であり, 計算值の7.87 wt \% と良い一致を示した。

以上 ${ }^{1} \mathrm{H}-\mathrm{NMR},{ }^{13} \mathrm{C}-\mathrm{NMR}$ りの構造推定, 微量元素分 析值による組成確認とEIアススペクトルよる分子量求よ び組成の確認により，単離された化合物は新規な㻴状木 ルマールである $1,3,5,7,10$ ペンタオキサシクロドデカン であることが同定された。

\section{2 初期反応過程の解析}

新規な反応中間体は新規な環状化合物である $1,3,5,7,10$ ペンオキサシクロドデカンと同定された。この化合物 は1モルのトリオキサンと2 モルのエチレンオキシドと の直接反応という新しい反応により生成すると推定され た(式 1)。

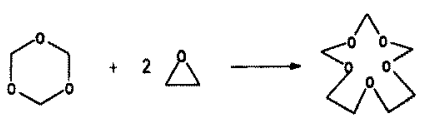


図4に実験デー夕を示す．前報13)にも報告したように 最初にエチレンオキシドの濃度の減少と共に $1,3,5,7$-テ トラオキサシクロノナンが生成することがわかる．また 1,3,5,7ーテトラオキサシクロノナンの生成と同時に 1,3,5,7,10-ペンタオキサシクロドデカンも生成している.

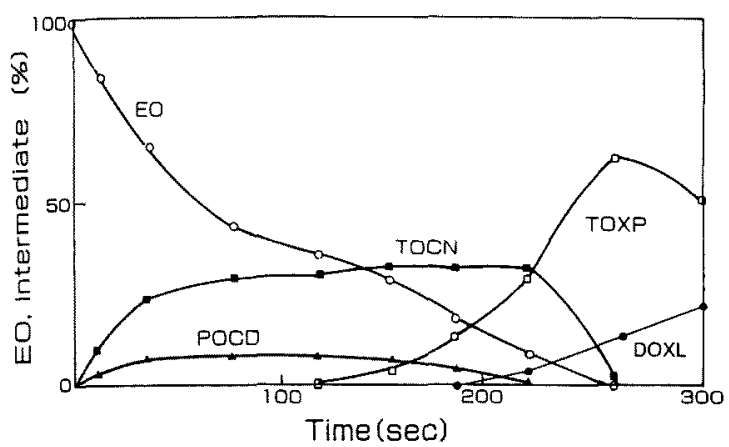

Fig. 4 Concentration profile of reactant of trioxane and ethylene oxide EO: ethylene oxide, TOCN: 1,3,5,7-tetraoxacyclononane, TOXP: $1,3,5$ trioxepane, DOXL: dioxolane, POCD: 1,3,5,7,10-pentaoxacyclododecane

1,3,5,7,10-ペンタオキサシクロドデカンの生成および 消隇の挙動は1，3，5，7-テトラオキサシクロノナンの挙動 とよく似ている，すなわちエチレンオキシドの消費と共 に両者は反応初期には增大し，しかる後減少し，エチレ ンオキシドの消隇と共に1,3，5，7-テトラオキサシクロ， ナンも消隇し，また， $1,3,5,7,10$-ペンタオキサシクロド テカカンも1,3，5,7-テトラオキサシクロノナンよりも若干 早めであるが消滅している。かかる反応挙動からみると, 1,3,5,7,10-ペンタオキサシクロドデカンの生成機構は 1,3,5,7-テトラオキサシクロノナンにエチレンオキシド 加付加する逐次反応よりも，卆しろ1モルのトリオキサ ンと2モルのエチレンオキシドが直接反応して生成する

機構のように推定される.

1,3,5,7-テトラオキサシクロノナンの場合には1 3,3 トリオキセパンを経て1,3-ジオキソランへと経時的に他 の物質へと変換している.これは9 員環化合物である1，3，5,7テトラオキサシクロノナンは環の歪みエネルギーが7員 環化合物である1，3，5-トリオキセパンあるいは 5 員環化 合物である1３-ジオキンランよりもはるかに大きいため, 5 員環化合物， 7 員環化合物に比してエネルギー的に不 安定であるためと推測された ${ }^{14)}$.一方 $1,3,5,7,10$-ペン夕 オキサシクロドデカンの場合にはかかる経時的な変換よ りも，直接開環重合反応が優先しているように見える. おそらく環の歪みエネルギーが 12 員環化合物である
$1,3,5,7,10$-ペンタオキサシクロドデカンとそれかららル ムアルデヒドが1分子脱離した10員環化合物との歪み工 ネルギーの差が小さいことによるものと推定される。し かしながら、この点については，正確にはさらにより詳 細な検討を必要とするように思える。

工業ベースでのトリオキサンとエチレンオキシドの共 重合体中のエチレンオキシドのシークエンス分布を調ヘ るために酸性水溶液の条件下で加熱してア七タールコポ リマーを加水分解する方法が知られている。この際にエ チレングリコールの他にジエチレングリコールなどが見 出されている。エチレングリコールは 1 個のオキシエチ レンユニットの両僋がオキシメチレンで囲まれている単 位から発生したと考之られる。また，ジエチレングリコ ールは 2 個の連続したオキシエチレンユニットがオキシ メチレンで围まれている単位から発生したと考えられる。 エチレングリコールとジエチレングリコールの量はオキ シエチレンユニット換算で大略 7：3である ${ }^{15)}$.これは 本研究で見出されている1,3，5，7-テトラオキサシクロ， ナンと $1,3,5,7,10$-゚ンタオキサシクロドデカンとの量比 とほほ近い值にある。

以上本研究の結果を緾めると、トリオキサンとエチレ ンオキシドとの共重合の初期反応過程では，1モルのト リオキサンと 1 モルのエチレンオキシドとの反応に基づ 〈1,3,5,7-テトラオキサシクロノナンが主成分として生 成する。さらにその他に少量成分として新しい構造の環 状化合物が見出されたここ化合物の化学構造を ${ }^{1} \mathrm{H}-\mathrm{NMR}$, ${ }^{13} \mathrm{C}-\mathrm{NMR}$, 質量分析, 元素分析により，1,3,5,7,10-ぺ ンタオキサシクロドデカンと同定した。この新規な環状 ホルマールは，1モルのトリオキサンと 2 モルのエチレ ンオキシドとの直接反応に基づき生成していると思われ る. 工業材料としてのアセタールコポリマーであるトリ オキサンとエチレンオキシドとの共重合体中には 2 個の 連続したオキシエチレンユニットが存在しているが、こ れは新規な環状ホルマールである1,3,5,7,10-ペンタオキ サシクロドデカンの開環重合により生成しているものと 推测される。

本研究の一部は平成 9 年度繊維学会年次大会研究発表会 (東京，1997年 6 月)で発表した。

\section{交献}

1. C. E. Schweitzer, R. N. MacDonald and J. O. Punderson, J. Appl. Polym. Sci, 1, 158 (1959).

2. T. A. Koch and P. E. Lindvig, J. Appl. Polym. Sci., 1, 164 (1959). 
3. W. H. Linton and H. H. Goodman, J. Appl. Polym. Sci., 1, 179 (1959).

4. Y. Kobayashi, I. Suzuki and S. Ishida, Hydrocarbon Processing, 51 (11), 111 (1972).

5. L. M. Blair, Technical Pap. Reg. Tech. Conf.Soc. Plast. Eng. Southeast Ohio Sec., 164 (1976).

6. K. Matsuzaki, T. Hata, T. Sone and J. Masamoto, Bull. Chem. Soc. Jpn., 67, 2560-2566 (1994)

7. K. Weissermel, E. Fisher and K. Gutweiler, Kunstoffe, 54, 410(1964).

8. K. Weissermel, E. Fisher, K. Gutweiler, H. D. Hermann and H. Cherdron, Angew. Chem., Int. Ed., Engl., 6, 526 (1967).

9. M. B. Price and F. B. McAndrew, J. Macromol. Sci. A-1 2, 231 (1967).
10. C. S. Chen and EdWard, Adv. Chem. Ser., 911, 359 (1968).

11. C. S. Chen and EdWard, J. Macromol. Sci.Chem., A4, 349(1970).

12. G. L. Collins, R. K. Greene, F. M. Beeradinelle and W. H. Ray, J. Polym. Sci. Polym. Chem. Ed., 19, 1597 (1981).

13. Junzo Masamoto, Naoaki Yamasaki, Wataru Sakai, Takashi Itoh, Naoto Tsutsumi, Nobuaki Ohnishi, and Hajime Nagahara, Sen'iGakkaishi, 54, 167 (1998).

14. P. Kubisa, in "Cationic Polymerization: Mechanism, Synthesis, and Applications" ed. by K. Matyjaszewski, Dekker, New York, 1995, pp. 437. 553.

15. Junzo Masamoto, unpublished results 